\title{
Ilmu Tegangan Pertumbuhan Dan Peneresan Pohon \\ Sebagai Satu Wujud Teknologi Kayu Berbasis Kearifan Lokal Budaya Jawa
}

Oleh

\author{
Ir. Yustinus Suranto, M.P \\ Dosen Fakultas Kehutanan Universitas Gadjah Mada, Yogyakarta
}

\section{Pendahuluan}

Ketika berlangsung proses Pelatihan Konservasi Bahan Kayu yang dilaksanakan pada tanggal 20 September s.d 3 Oktober 2010 oleh Balai Konservasi Peninggalan Borobudur dalam rangka meningkatkan kapasitas para pelestari Benda dan Bangunan Cagar Budaya (BCB), penulis sebagai pemateri menerima banyak pertanyaan dari para peserta pelatihan. Di dalam pertanyaan-pertanyaan itu, terdapat dua orang peserta yang mengajukan pertanyaan yang intinya sama, tetapi disampaikan dengan formulasi yang berbeda. Seorang peserta bertanya: "Mengapa nenek moyang kita memiliki tradisi tertentu dalam kaitan dengan penebangan pohon, yaitu bahwa pohon itu dithethaki terlebih dahulu sebelum pohon tersebut ditebang pada saat tertentu yang ditentukan berdasarkan pada perhitungan pranoto-mongso. Menurut informasi umum yang sulit dilacak dasar argumentasinya, tradisi nenek moyang tersebut dilakukan sebagai upaya agar mereka mendapatkan kayu yang berkualitas tinggi untuk digunakan sebagai bahan membuat komponen bangunan rumah. Adakah kebenaran yang terkandung di dalam tradisi ini dan apakah tradisi ini dapat dipertanggung-jawabkan?”. Pada sesi yang sama di dalam diskusi tersebut, seorang peserta lainnya juga mengajukan pertanyaan yang disampaikan dengan ungkapan berikut: "Mengapa pohon perlu diteres selama beberapa waktu, kemudian baru dilakukan penebangan terhadap pohon tersebut?"

Dua pertanyaan itu sangat menarik bagi penulis bila dilihat dari empat butir pendapat berikut. Pertama, dua pertanyaaan dari dua peserta tersebut memiliki inti pertanyaan yang sama, yakni mempertanyakan tentang ilmu yang menjadi basis pembenaran dan rasionalitas pemahaman terhadap peneresan pohon sebagai salah satu wujud praktek tradisi budaya etnik jawa yang berkait dengan teknologi kayu. Kedua, penanya kedua mungkin tidak begitu memahami arti kata dithethaki dan kata pranotomongso sebagai terminologi bahasa Jawa. Hal ini terlihat dari sikapnya untuk tetap mengajukan pertanyaan yang intinya sama. Ketiga, keilmuan yang melatar-belakangi rasionalitas tradisi berupa aktivitas netbaki pohon atau peneresan pohon itu merupakan informasi yang bernilai sangat penting. Oleh karena itu sangat diinginkan untuk diketahui oleh peserta. Keempat, berdasarkan pada pertimbangan yang tercantum di dalam butir pertama dan butir ketiga di atas, maka kiranya sangatlah bermanfaat untuk menyajikan suatu tulisan ilmiah tentang keilmuan kayu yang dapat dijadikan landasan rasional tentang pelestarian tradisi peneresan pohon bagi para pelestari BCB.

Tulisan ini diharapkan agar dapat digunakan sebagai sarana pemahaman bagi para pelestari BCB, sehingga para pelestari ini memiliki sikap tidak ragu-ragu di dalam melakukan tradisi peneresan, terutama ketika harus mengadakan kayu sebagai bahan pengganti bagi komponen bangunan yang terpaksa harus diamputasi atau bahkan diganti sepenuhnya pada proses pemugaran BCB berbahan kayu. Di samping itu, dengan bekal pemahaman ini, para pelestari juga diharapkan memiliki sikap lebih percaya diri ketika melakukan aktivitas sosialisasi atau mengkampanyekan pelestarian tradisi peneresan ini kepada masyarakat. Tradisi-tradisi, tak terkecuali tradisi teknologi kayu dalam wujud peneresan pohon sebagai awal proses penebangannya, memang perlu disosialisasikan, mengingat bahwa praktek-praktek kehidupan yang berbasiskan pada tradisi sebagai perwujudan atas kearifan lokal ini dipercayai akan menjadi inspirasi dan sarana bagi generasi sekarang untuk mengatasi permasalahan global, sebagaimana amanat yang dihasilkan dalam pertemuan para pakar tingkat dunia pada workshop internasional bertopik "Local Wisdom Inspiring Global Solutian" yang digelar oleh Universitas Gadjah Mada pada tanggal 5 - 8 Desember 2010.

Untuk mempermudah bagi para pelestari $\mathrm{BCB}$ memahami isi tulisan ini, maka tulisan akan disusun dengan sistematika yang terdiri atas enam sub-bab berikut. Pertama, Proses-proses Fisiologis Pohon. Kedua, Proses Pembentukan Kayu dan Pertumbuhan Pohon. Ketiga, Tegangan Pertumbuhan Pohon dan Potensi Kerusakan Kayu. Keempat, Peneresan Pohon dan Kematian Pohon. Kelima, Penurunan Kadar Air dan Kadar Pati serta Pelepasan Tegangan Pertumbuhan. Keenam, Peningkatan Kualitas Kayu sebagai Akibat Peneresan. Masing-masing sub-bab ini disajikan dalam uraian berikut.

\section{Proses-proses Fisiologis Pohon}

Proses-proses fisiologis pohon merupakan berbagai proses yang berlangsung di dalam pohon sebagai 
makhluk hidup. Dengan proses-proses fisiologis itu, suatu pohon mampu untuk mempertahankan hidupnya dan memperbesar dimensi dirinya serta berkembang-biak. Beberapa proses penting dari proses fisiologi pohon meliputi absorbsi, translokasi, fotosintesis, metabolisme nitrogen, respirasi, asimilasi, transpirasi, pertumbuhan, reproduksi. Setiap proses fisiologis pohon diuraikan sebagai berikut.

Absorpsi merupakan proses penyerapan air dan mineral dari tanah oleh akar, khususnya bagian rambut akar (Brady, 1981). Di samping itu, pohon juga mengabsorbsi zat karbon-dioksida dan oksigen dari udara melalui daun, khususnya bagian stomata daun. Air dan garam mineral ini dialirkan menuju ke daun. Pengaliran berlangsung melalui kayu, terutama bagian kayu gubal, yang ada pada: akar, batang, cabang dan ranting. Proses perpindahan air dan garam mineral yang berlangsung di dalam pohon ini disebut translokasi (perpindahan).

Sesampainya di daun, terutama pada bagian khlorofil, air yang mengandung mineral ini direaksikan dengan karbon dioksida dan terbentuklah glukosa dan oksigen. Reaksi ini hanya dapat berlangsung bila dibantu oleh adanya sinar matahari. Oleh karena itu, prosesnya disebut fotosintesis. Glukosa yang berada di dalam daun ini kemudian mengalami proses translokasi menuju ke seluruh sel penyusun pohon tersebut, khususnya sel yang masih hidup (Baker dkk, 1979). Perpindahan glukosa dari daun menuju ke seluruh sel yang masih hidup tersebut berlangsung melalui kulit-bagian-dalam (phloem) dan sel kayu, khususnya sel yang masih hidup, yaitu sel parenkim dan sel jari-jari. Glukosa merupakan monomer yang akan digunakan sebagai bahan dasar untuk disintesis untuk menjadi berbagai unsur-unsur kimia tumbuhan, baik berupa karbohidrat (pati), protein, enzim, hormon, ekstraktif, pati atau karbohidrat, selulosa, hemiselulosa dan lignin. Proses sintesis ini secara umum disebut proses polimerisasi.

Sebagaimana disebutkan, bahwa air digunakan sebagai bahan dasar di dalam proses fotosintesis. Di samping sebagai bahan dasar, sebagian dari air itu di dalam bentuk uap juga dilepaskan dari pohon menuju ke udara yang melingkupinya. Proses pelepasan air ini disebut sebagai proses transpirasi. Keberlangsungan proses transpirasi ini akan menjadi salah satu pendorong bagi berlangsungnya proses absorbsi air dan garam mineral oleh akar.

Di dalam sel-sel yang hidup tersebut, karbohidrat atau pati ini mengalami proses respirasi, yaitu proses pengoksidasian karbohidrat untuk memperoleh energi. Energi digunakan sebagai sumber daya yang diperlukan untuk melaksanakan seluruh proses fisiologis yang berlangsung di dalam pohon. Proses respirasi ini disertai oleh proses pencernaan. Pencernaan merupakan proses yang melibatkan aktivitas enzim dalam rangka pengubahan pati atau karbohidrat sebagai bentuk makanan yang kompleks dan tidak larut, menjadi bentuk makanan yang lebih sederhana dan larut, semisal glukosa. Karena berada dalam kondisi yang dapat terlarut, maka glukosa ini dapat ditranslokasikan serta dioksidasi atau digunakan untuk proses fisiologis lainnya.

Di samping sebagai bahan untuk diubah menjadi energi, glukosa juga digunakan sebagai bahan dasar di dalam proses polimerisasi untuk menyusun unsur-unsur kimia kayu. Di dalam konteks ini, ada proses metabolisme nitrogen, yakni proses sintesis persenyawaan nitrogen organik dari nitrogen anorganik dalam rangka persiapan untuk mensintesis protein protoplasma. Di samping itu, juga terdapat proses asimilasi, yaitu proses pengubahan karbohidrat menjadi protoplasma baru, dan dinding sel (yang tersusun atas selulosa, hemiselulosa, dan lignin) serta bagian-bagian sel lainnya (antara lain sitoplasma, nucleus dan nucleolus).

Semua proses itu akan bermuara pada pembentukan biomassa, baik berupa kayu maupun sarana reproduksi. Pembentukan kayu akan mengarah pada penambahan dimensi fisik pohon, baik dimensi meninggi maupun dimensi membesar. Sementara itu, sarana reproduksi pohon akan mengarah pada perkembangbiakan (regenerasi) tetumbuhan yang berupa bunga, produksi buah dan biji (Sabarnurdin, 1978).

\section{Proses Pembentukan Kayu dan Pertumbuhan Pohon}

Sebagaimana disebutkan, bahwa proses fotosintesis akan menghasilkan glukosa. Glukosa mengalami proses polimerisasi secara bertahap untuk membentuk lima macam unsur kimia, yaitu selulosa, hemiselulosa, lignin, zat ekstraktif dan zat mineral. Unsur kimia yang mana yang akan dibentuk lebih dulu pada suatu waktu, dan unsur kimia yang mana yang dibentuk selanjutnya, serta bagaimana urutan proses pembentukan bagi masing-masing unsur kimia tersebut, pada saat ini masih merupakan misteri (rahasia) alam. Kelima unsur kimia itu saling bereaksi sehingga terbentuk ligno-selulosa, antara lain berupa kayu (Prayitno, 2007).

Selulosa merupakan hasil polimerisasi dari monomer dasar yang disebut glukosa atau monosakarida. Prinsip struktur monosakarida adalah $\mathrm{C}_{6} \mathrm{H}_{12} \mathrm{O}_{6}$ atau hexopyranoses hanya untuk turunan dari struktur cincin. Sepasang monosakarida berikatan dengan ikatan glikosidik membentuk disakarida, antara lain berupa selobiosa dan maltobiosa. Selobiosa ini mengalami polimerisasi lebih 
lanjut dengan derajat polimerisasi yang sangat tinggi sehingga terbentuk selulosa. (Prayitno, 2007).

Pada jalur sintesis yang lain, glukosa akan mengalami polimerisasi sehingga terbentuk beberapa polimer, yaitu (1) xiloglukan, (2) glukorono-arabino-xilan, (3) xilan, (4) mannan dan (5) kalose sebagai campuran rantai glukan yaitu $\beta 1.3$ glukan dan $\beta 1.3-\beta 1.4$ glukan dan (6) galaktomanan. Pelimer-polimer tersebut berinteraksi untuk menyusun hemiselulosa. Hemiselulosa memiliki bagian yang memiliki keterikatan dengan selulosa berupa ikatan hidrogen (Prayitno, 2007).

Pada jalur sintesis yang lain lagi, glukosa mengalami reaksi kimia sehingga terbentuk monolignol atau alkohol cinnamyl yang mencakup tiga jenis, yaitu alkohol p-coumaryl, alkohol coniferyl dan alkohol sinapyl. Ketiganya merupakan sub-unit aromatik dan berstatus sebagai monomer lignin. Monomer-monomer lignin ini mengalami polimerisasi yang mungkin berlangsung secara acak dan bersifat dehidro-generatif, sehingga terbentuk polimer lignin. Di dalam polimer lignin, residu monolignol saling-terhubung dengan berbagai ikatan. Di samping berikatan antar mono-lignol, residu ini dapat juga berikatan dengan polisakarida dan protein dan menghasilkan struktur tiga dimensi yang bermacam-macam dan kuat (Prayitno, 2007).

Zat ekstraktif berdasarkan susunan kimianya dibedakan lebih lanjut menjadi 5 kelompok, yaitu (1) karbohidrat (pati), gula alkohol, siklita dan asam turunan siklita, (2) Asam amino, protein dan ensim, (3) lemak dan asam lemak, (4) terpena, terpenoida, tropolona dan stereoida, (5) senyawa karbosiklis, khinon dan alkaloida (Prayitno, 2007).

Proses polimerisasi dalam rangka membentuk zatzat kimia kayu tersebut berlangsung seirama dengan proses pertumbuhan pohon. Berdasarkan tempat berlangsungnya proses, pertumbuhan pohon dibedakan menjadi dua macam, yaitu pertumbuhan primer dan pertumbuhan sekonder (Soenardi, 1977). Pertumbuhan primer adalah pertumbuhan yang berlangsung pada setiap bagian pucuk pohon. Pada pertumbuhan primer, kayu yang baru saja terbentuk ditambahkan pada bagian ujung-ujung pohon yang ada pada pucuk-pucuk ranting atau tunas. Dengan demikian, pertumbuhan primer akan mengakibatkan pertambahan dimensi tinggi pohon.

Sementara itu, pertumbuhan sekunder adalah pertumbuhan yang berlangsung pada kambium pohon. Pada pertumbuhan sekunder, kayu yang baru saja terbentuk ditambahkan pada posisi bagian terluar dari kayu yang telah ada, yakni kayu yang lebih dulu disintesis. Hal ini disebabkan karena kambium ini berada pada batas antara kayu dan kulit batang. Dengan demikian, pertumbuhan sekunder akan mengakibatkan pertambahan dimensi diameter kayu, baik diameter batang, diameter cabang maupun diameter ranting pohon (Kollmann dan Cote, 1968). Akumulasi kayu yang dibentuk selama satu tahun dikenal sebagai riap pertumbuhan. Akumulasi kayu yang terbentuk selama satu tahun ini akan tampil sebagai lingkaran-lingkaran kayu, yang akan tampak pada penampang melintang batang. Lingkaran-lingkarankayu ini disebut lingkaran tahun.

Pertumbuhan pohon dapat dikenali secara bertahap dari perkembangan status dirinya. Semula, tetumbuhan berstatus sebagai biji, kemudian mengalami pertumbuhan menjadi kecambah. Dari status kecambah ini, tetumbuhan ini mengalami pertumbuhan lebih lanjut dan berdasarkan dimensi tinggi tetumbuhan dan atau diameter batangnya, status tetumbuhan itu berturut-turut berubah menjadi semai, sapihan, tiang, dan akhirnya menjadi pohon.

\section{Tegangan Pertumbuhan Pohon dan Potensi Kerusakan Kayu}

Dari sub-bab di atas, dapat dipahami bahwa pertumbuhan primer pohon berlangsung dengan menambahkan kayu baru pada bagian pucuk-pucuk pohon dan tunas-tunas pada ranting pohon. Dengan demikian, kayu baru sebagai hasil proses sintesis tersebut selalu ditambahkan di atas kayu yang lebih dulu terbentuk, sehingga kayu yang lebih dulu terbentuk selalu tertindih oleh kayu baru yang proses pembentukannya meliputi pembedaan fungsi (deferensiasi), pembesaran sampai mencapai ukuran maksimum, penebalan dinding sel sekunder dengan pengendapan lignin yang semakin lama semakin intensif (lignifikasi) (Soenardi, 1977). Oleh karena itu, kayu yang lebih dulu terbentuk juga mendapat tekanan oleh gaya berat kayu-kayu yang disintesis pada saat-saat berikutnya ditambah lagi dengan tekanan dari kayu yang baru saja disintesis.

Sementara itu, dapat dipahami pula bahwa pertumbuhan sekunder batang berlangsung dengan menambahkan kayu baru pada kayu yang lebih dulu terbentuk yang berlokasi pada bagian terluar, yaitu pada berbatasaan kayu dengan kambium dan kulit batang. Dengan demikian, kayu hasil sintesis baru tersebut selalu ditambahkan di bagian terluar kayu yang lebih dulu terbentuk, sehingga kayu yang lebih dulu terbentuk itu selalu mendapat gaya tekan oleh kayu-kayu yang disintesis pada saat-saat berikutnya, ditambah lagi dengan gaya tekan dari kayu yang baru disintesis. Sebagaimana disebutkan, bahwa proses sintesis sel berlangsung dalam tahap diferensiasi sel, pembesaran sel, penebalan dinding sekunder, dan lignifikasi dinding sel kayu. Proses 
pembesaran sel sehingga mencapai ukuran maksimum dan diikuti dengan penebalan dinding melalui preses lignifikasi ini akan menyebabkan pengembangan sel ke arah transversal, sekaligus menyebabkan pemendekan sel dalam arah longitudinal. Mengingat bahwa sel-sel baru ini tersusun di dalam kayu, dalam kondisi padat yang terdiri atas sel-sel, maka pemendekan ini tidak dapat diaktualisasikan secara bebas. Hal ini disebabkan karena upaya memendek itu dihalangi oleh sel yang lebih dulu terbentuk yang ada disampingnya. Dengan demikian, selsel yang baru terbentuk itu berada di dalam kondisi tertarik ke arah longitudinal oleh sel-sel yang ada disampingnya, sehingga ukuran panjangnya relatif sama dengan ukuran panjang sebelum mengalami penebalan. Sel yang berada di dalam kondisi ditarik ini disebut sebagai sel yang mengalami tarikan (tension). Sebaliknya, sel-sel yang ada disamping sel baru tersebut mengalami kondisi tekanan. Tekanan kayu ini mengarah kepada pusat kayu atau empulur. Dengan demikian, kayu yang dibentuk pada tahap yang semakin awal akan semakin besar menerima tekanan, karena tekanan ini bersifat kumulatif (Archer, 1986).

Tegangan yang mengalami oleh kayu karena adanya tekanan yang berasal dari kayu baru yang dibentuk baik oleh pertumbuhan primer maupun pertumbuhan sekonder seirama dengan proses pertumbuhan pohon itu disebut Tegangan Pertumbuhan (Growth stress). Kayu yang posisinya semakin dekat dengan empulur (pusat batang), maka kayu tersebut akan mengalami tegangan pertumbuhan yang semakin besar. Sebaliknya, kayu yang posisinya semakin dekat terhadap kulit batang, maka kayu tersebut akan mengalami tegangan pertumbuhan yang semakin kecil. Dengan demikian, besarnya tegangan pertumbuhan yang dialami oleh kayu semakin meningkat sesuai dengan posisi kayu yang semakin mendekat pada pusat batang (empulur). Dengan kata lain, ada perbedaan besarnya tegangan pertumbuhan yang dialami oleh kayu sesuai dengan posisi masing-masing lingkaran tahun di dalam batang. Di dalam konteks ini, dikatakan bahwa kayu di dalam masing-masing lingkaran tahun di dalam batang mengalami gradien tegangan pertumbuhan.

Secara umum, dapat dikatakan bahwa lingkaran tahun pada kayu yang dibentuk pada tahap awal akan mendapat desakan dari lingkaran-lingkaran tahun yang dibentuk sesudahnya. Dengan demikian, semakin mendekati empulur posisi lingkaran tahun, semakin besar tegangan pertumbuhan yang dialaminya, karena tegangan pertumbuhan ini bersifat akumulatif dari tegangantegangan pertumbuhan yang dihasilkan dari lingkaranlingkaran tahun yang dibentuk sesudahnya. Tegangan pertumbuhan ini akan menyebabkan serat-serat kayu menjadi getas, sehingga serat kayu ini mudah putus pada bagian tengah serat tersebut.

Besarnya tegangan pertumbuhan dapat diukur pada pohon yang masih hidup dan masih berdiri. Pengukuran yang cukup mutakhir dilakukan dengan cara menempelkan alat berupa "strain gange" pada bagian kayu yang terluar, yaitu kayu yang kelihatan ketika kulit batang dan kambium dikupas. Bagian kayu yang ditempeli "strain gange" kemudian dilepaskan dari batang dengan menggunakan gergaji dan tatah. Penyusunan dimensi "strain gange" akan dicatat di dalam peralatan "data logger" dan komputer mikro yang menyertainya (Archer, 1986).

Tegangan pertumbuhan yang dialami oleh kayu tersebut akan dilepaskan pada saat pohon itu ditebang. Di samping itu, pelepasan tegangan pertumbuhan ini masih akan berlangsung ketika kayu gelondong yang berasal dari batang pohon itu digergaji menjadi sortimen-sortimen kayu persegian. Dipahami bahwa kayu persegian ini dapat berupa balok atau papan yang akan digunakan sebagai komponen bahan bangunan.

Batang yang mengalami tegangan pertumbuhan yang semakin besar dengan distribusi tegangan pertumbuhan yang semakin tidak merata di antara kayu pada lingkaran-lingkaran tahun, maka kayu batang pohon ini memiliki kemungkinan yang semakin besar untuk mengalami kerusakan ketika berlangsung proses penebangan pohon. Kerusakan kayu ini akan berupa cacat pecah dan terbelah ketika berlangsung proses penebangan pohon dan sering kali terlihat adanya batang pohon yang "njepat" terbelah ke arah vertikal sebelum batang itu menjadi rebah sepenuhnya dan proses penebangan pohon belum sepenuhnya dapat diselesaikan. Kondisi demikian sering kali juga didahului oleh adanya kesulitan bagi bilah gergaji ketika untuk bergerak secara translasi ketika sedang difungsikan untuk menebang batang. Kesulitan ini disebabkan karena bilah gergaji dihimpit oleh kayu yang sedang mengaktualisasikan pelepasan tegangan pertumbuhan. Kondisi demikian akan dialami oleh batang yang memiliki tegangan pertumbuhan yang sangat besar, dan distribusi tegangan pertumbuhan yang tidak merata di antara kayu pada masing-masing lingkaran tahun, serta sel seratnya telah menjadi getas karena adanya pembentukan bidang patah pada pertengahan sumbu longitudinalnya.

Pelepasan tegangan pertumbuhan juga terus berlangsung pada proses penggergajian kayu bulat gelondong menjadi kayu gergajian. Pada kayu yang mengalami tegangan pertubuhan yang besar dengan distribusi yang tidak merata, maka pelepasan tegangan pertumbuhan akan mengakibatkan kayu gergajian tersebut mengalami cacat, antara lain berupa retak, pecah, terbelah atau cacat terpuntir. Adanya cacat pada kayu, baik yang terjadi pada proses penebangan maupun pada proses penggergajian, akan sangat merugikan. Hal ini disebabkan 
karena keberadaan cacat kayu tersebut mengakibatkan penurunan kuantitas (volume kayu) yang dapat digunakan dan penurunan kualitas kayu yang akan digunakan. Penurunan kuantitas dan kualitas kayu ini pada gilirannya sudah tentu juga akan disertai oleh penurunan nilai ekonomi kayu (Archer, 1986).

Di dalam konteks teknologi kayu, ilmu tegangan pertumbuhan merupakan ilmu yang relatif baru. Ilmu tegangan pertumbuhan baru mulai berkembang pada tahun 1940-an melalui penelitian-penelitian yang dipelopori Jacobs, seorang akhli kayu dari Eropa. Jacobs pulalah yang pertama kali diperkenalkan penggunaan terminologi Growth stress (tegangan pertumbuhan) pada tahun 1945 untuk menamai tegangan dan regangan mekanis yang dialami oleh kayu seirama dengan proses pertumbuhan pohon. Sejak saat itu, penelitian tentang tegangan pertumbuhan pohon terus dilakukan hampir seluruh wilayah geografis di muka bumi, tidak terkecuali di Indonesia. Penelitian terhadap tegangan pertumbuhan pohon-pohon yang tumbuh di Indonesia sebagian besar dilakukan atas kerja sama antara ahli-ahli kayu Indonesia dan Jepang yang dimulai pada tahun 1990-an dan penelitian itu masih berlangsung sampai saat ini.

\section{Peneresan Pohon dan Proses Kematiannya.}

Penebangan pohon merupakan suatu proses pemanenan kayu yang terdiri atas serangkaian aktivitas. Menurut teknologi kayu yang disarankan di dalam tradisi budaya Jawa, aktivitas penebangan pohon ini meliputi sekurang-kurangnya lima aktivitas, yaitu: (1) Penentuan pohon yang akan ditebang, (2) penentuan waktu pelaksanan penebangan pohon, (3) peneresan pohon, dan (4) penebangan pohon serta (5) pembagian batang dalam arah aksial.

Aktivitas penentuan pohon dilakukan dengan tujuan untuk memilih pohon mana yang akan ditebang dan pohon mana yang belum saatnya ditebang. Pemastian itu dilakukan dengan berlandasan pada pedoman berbasis tradisi, yaitu bahwa pohon yang akan ditebang merupakan pohon yang telah berusia tua, semisal berusia minimal 80 tahun bagi pohon jati. Sementara itu, aktivitas penentuan masa penebangan dilakukan dengan berpedoman pada basis tradisi, yaitu bahwa penebangan itu harus dilakukan pada masa tertentu di dalam konteks "pranoto-mongso". Di dalam konteks ini, penebangan pohon harus dilakukan pada "mongso-tuwo" dan sama sekali tidak boleh melakukan penebangan pada saat "mongso-enom", terhadap pohon bahkan telah berusia tua yang telah dipilih tersebut. Setelah ditentukan pohon mana yang akan ditebang, dan setelah ditentukan pula saat "mongsotuwo" itu secara tepat, maka dilakukan aktivitas ketiga, yaitu peneresan pohon. Dengan demikian, peneresan pohon juga dilakukan pada sat "mongso-tuwo". Peneresan pohon merupakan salah satu aktivitas pertama di dalam serangkaian proses penebangan pohon di dalam rangka memanen kayu untuk mendapatkan bahan yang akan digunakan sebagai komponen bangunan.

Peneresan pohon adalah aktivitas pengelupasan kulit batang dan kambium pada bagian pangkal batang, agar kambium dan kulit batang tersebut terpisah dan terlepas dari pohon yang akan ditebang. Sudah tentu pohon yang diteres ini merupakan pohon yang masih hidup. Pelepasan kulit dan kambium batang dilakukan secara melingkar penuh. Bagian kulit dan kambium yang dikelupas dan dihilangkan berukuran sepanjang 15 s.d 20 $\mathrm{cm}$ dalam arah aksial batang. Dengan demikian, kulit dan kambium yang menyelimuti di batang bagian bawah dan akar pohon terpisah sepenuhnya terhadap kulit dan kambium yang menyelimut di batang bagian atas dan tajuk pohon. Realitas penghilangan kulit pada bagian pangkal batang pohon inilah yang melahirkan terminologi bahasa Jawa dengan ungkapan pohon "dithethake?". Peneresan bersinonim dengan kata "girdling" dalam bahasa inggris.

Pohon ini dibiarkan dalam kondisi diteres atau "dithethake?" selama satu sampai dengan dua tahun. Akibat peneresan ini, pohon itu akan mati secara perlahan-lahan. Kematian pohon ini disebabkan oleh karena adanya pemutusan hubungan antara kambium dan kulit batang yang ada di atas bagian yang diteres terhadap kambium dan kulit batang yang ada di bawah bagian yang diteres. Terputusnya kesinambungan hubungan kambium dan kulit pohon mengakibatkan terhentinya proses transportasi (translokasi) enzim pertumbuhan dan glukosa sebagai zat makanan yang berasal dari daun menuju ke bagian perakaran pohon, sehingga bagian perakaran tidak lagi memiliki energi dan daya tumbuh. Ketiadaan energi dan daya tumbuh pada bagian perakaran pohon mengakibatkan proses penyerapan (absorbsi) air dan garam mineral oleh akar, khususnya bagian akar rambut, tidak dapat dilakukan, demikian pula proses pengalirannya (translokasi) menuju ke daun.

Mengingat bahwa air dan garam mineral merupakan bahan dasar untuk proses fotosintesis pada daun, maka ketiadaan air dan garam mineral pada daun ini mengakibatkan tidak berlangsungnya proses fotosintesis. Dengan demikian, maka daun tidak membentuk glukosa sebagai sumber energi dan sumber ligno-selulosa lagi, bahkan daun akan menjadi layu dan mengering karena terbakar oleh sinar matahari. Akhirnya, daun ini luruh dan jatuh terserak di atas tanah.

\section{Penurunan Kadar Air dan Kadar Pati serta Pelepasan Tegangan Pertumbuhan.}

Narasi yang tertuang pada sub bab 4 di atas 
memberi pemahaman, bahwa air dan garam mineral tidak lagi dapat dikirim oleh akar menuju ke daun. Mengingat bahwa transportasi air dan garam mineral ini dilakukan melalui kayu, khususnya kayu gubal, maka terhentinya transportasi air ini akan mengakibatkan kayu yang ada pada batang dan cabang serta ranting pohon yang masih berdiri itu akan menjadi lebih kering. Dengan kata lain, kadar air kayu akan menjadi turun sebagai akibat peneresan pohon. Hasil penelitian Yamamoto dkk (1998) membuktikan hal itu. Penurunan kadar air kayu batang mengakibatkan dua konsekuensi berikut. Pertama, kayu akan menjadi lebih ringan. Kedua, kayu akan menjadi lebih elastis, tidak getas dan tidak mudah patah.

Pada proses penebangan, maka rebahnya pohon dapat dipahami sebagai adanya benturan antara kayu dengan permukaan tanah. Kayu yang memiliki massa yang lebih ringan akan menghasilkan gaya gravitasi yang lebih kecil, sehingga gaya benturan yang terjadi antara kayu dan permukaan tanah juga menjadi lebih kecil. Sementara itu, tingkat elastisitas kayu yang lebih tinggi akan mengakibatkan kayu tidak mudah mengalami kerusakan sebagai akibat dari adanya benturan yang dialamainya dengan permukaan tanah tersebut di dalam proses penebangan pohon.

Peneresan pohon yang mengakibatkan kematian pohon ini ternyata juga mempengaruhi tegangan pertumbuhan yang dialami oleh kayu. Hasil penelitian Yamamoto dkk (1998) juga membuktikan, bahwa pengaruh ini berlangsung di dalam dua gatra. Pertama, kayu akan mengalami penurunan tingkat tegangan pertumbuhan yang ada padanya sebagai akibat dari adanya peneresan pohon. Dengan demikian, maka tingkat tegangan pertumbuhan yang dialami oleh kayu menjadi lebih kecil ukurannya, terutama pada kayu yang berada di dekat empulur. Kedua, distribusi tegangan pertumbuhan di antara kayu pada masing-masing lingkaran tahun juga lebih merata, sehingga besarnya tegangan pertumbuhan pada masing-masing lingkaran tahun juga lebih keseimbangan. Penyeimbangan distribusi tegangan pertumbuhan ini berlangsung dengan mekanisme berikut. Kayu yang berada di dekat empulur, tegangan pertumbuhan yang semula berukur besar akan diperkecil dimensinya. Sebaliknya, pada kayu yang berada di dekat kulit, tegangan pertumbuhan yang semula berukuran kecil akan diperbesar dimensinya.

Adanya penurunan tingkat tegangan pertumbuhan yang dialami oleh kayu mengakibatkan tegangan pertumbuhan yang dilepaskan ketika proses penebangan pohon berlangsung menjadi jauh lebih kecil. Sementara itu, pemerataan distribusi tegangan pertumbuhan di antara kayu penyusun masing-masing lingkaran tahun ini mengakibatkan berkurangnya tingkat perbedaan tegangan pertumbuhan antar kayu pada masingmasing lingkaran tahun, sehingga daya pemisah pada batas lingkaran tahun juga menjadi lebih kecil. Oleh karena itu, penurunan tingkat tegangan pertumbuhan yang secara simultan disertai juga dengan pemerataan distribusi tegangan pertumbuhan di antara kayu penyusun masingmasing lingkaran tahun akan membebaskan batang dari cacat pecah pada bagian pangkalnya atau terbelah ketika proses penebangan pohon berlangsung.

Peneresan pohon yang mengakibatkan kematian pohon ini ternyata juga mempengaruhi jumlah pati yang tersimpan di dalam kayu, khususnya di dalam jaringan parenkin kayu. Pengaruh ini berupa penurunan kadar pati yang tersimpan di dalam kayu. Penurunan kadar pati di dalam kayu ini berlangsung dengan mekanisme berikut. Peneresan pohon, sebagaimana disebutkan, akan mengakibatkan terhentinya aliran air dan garam mineral dari akar menuju ke daun. Mengingat bahwa air dan garam mineral ini merupakan bahan dasar di dalam proses fotosintesis, maka terhentinya air dan garam mineral ini berarti juga terhentinya proses fotosintesis. Dengan demikian, maka glukosa tidak lagi dapat disintesis. Sementara itu, proses metabolisme dan proses respirasi di dalam pohon masih terus berlangsung sejak awal proses peneresan sampai dengan kematian pohon itu yang ditandai dengan luruhnya dedaunan pohon tersebut. Proses metabolisme dan proses respirasi ini memerlukan energi. Energi diperoleh dari proses pengoksidasian terhadap glukosa atau karbohidrat atau pati. Mengingat bahwa glukosa tidak lagi terbentuk, maka karbohidrat atau pati yang diubah menjadi energi dalam proses respirasi ini merupakan karbohidrat atau pati cadangan, yakni pati yang disimpan di dalam jaringan parenkim sebagai cadangan sumber energi. Dengan demikian, pati sebagai cadangan sumber energi ini terus menerus diambil dari jaringan parenkim untuk dioksidasi di dalam proses respirasi. Semakin lama, pati sebagai cadangan energi akan habis dan pohon yang diteres itu akan mati karena aktivitas fisiologisnya tidak dapat diberlangsungkan lagi karena tidak lagi terdukung oleh ketersediaan energi.

Kayu yang tidak mengandung pati akan menjadi tidak menarik lagi bagi serangga penggerek kayu yang menjadikan kayu sebagai sumber pati sebagai bahan makanannya. Dengan demikian, kayu yang tidak lagi mengandung pati tidak lagi diminati oleh serangga penggerak kayu untuk menggereknya, sehingga kayu akan terhindar dari serangan serangga penggerak kayu. Pada akhirnya, kayu ini akan terbebas dari serangan serangga penggerek kayu, sehingga ketika kayu ini digunakan sebagai salah satu komponen suatu bangunan, maka kayu tersebut 
akan menjadi lebih awet.

\section{Peneresan Pohon Mengakibatkan Peningkatan Kualitas Kayu.}

Uraian pada sub-bab 5 di atas memberikan pemahaman bahwa peneresan pohon selama satu sampai dua tahun akan mengakibatkan lima perubahan terhadap kondisi kayu penyusun batang dibandingkan dengan kondisi kayu itu sebelum peneresan batang pohon. Kelima perubahan kondisi kayu ini meliputi: (1) kadar air kayu menjadi lebih rendah dan dengan demikian kayu menjadi lebih ringan, (2) elastisitas kayu menjadi lebih tinggi, (3) tegangan pertumbuhan yang dialami kayu menjadi lebih rendah, dan (4) distribusi tegangan pertumbuhan di antara kayu-kayu penyusun batang menjadi lebih merata dan seimbang, (5) kadar pati di dalam kayu menjadi lebih rendah, bahkan pada tingkat sangat minimum. Keempat butir yang pertama berkait dengan kondisi kayu penyusun batang ini akan lebih kondusif bagi proses penebangan pohon, karena batang kayu akan terhindar dari cacat retak, pecah maupun terbelah. Terhindarnya cacat kayu ini merupakan akibat dari pelepasan tegangan pertumbuhan yang berdaya kecil dan terdistribusi secara merata dan seimbang. Di samping itu, terhindarnya cacat kayu batang juga sebagai akibat dari rendahnya daya bentur antara batang pohon dan permukaan tanah serta meningkatnya elastisitas (kelenturan) kayu, yang juga berarti meningkatnya ketahanan kayu terhadap daya bentur.

Di samping lebih kondusif terhadap proses penebangan, kayu gelondong yang mengandung tegangan pertumbuhan pada tingkat yang rendah yang disertai dengan distribusi tegangan pertumbuhan yang merata dan seimbang ini juga kondusif bagi proses penggergajian yang mengubah kayu bulat gelondong menjadi kayu gergajian. Kayu gelondong yang demikian ini akan menghasilkan kayu gergajian yang bebas cacat, baik cacat perubahan bentuk yang berupa cacat-cacat: memuntir, melengkung, melekuk, memangkuk dan menggenjang, maupun cacat yang berupa retak, pecah dan terbelah. Terbebasnya kayu gergajian dari berbagai jenis cacat itu akan mengakibatkan peningkatan kualitas kayu gergajian, di samping juga peningkatan rendemen kayu gergajian yang diperoleh.

Sementara itu, butir nomor lima perubahan kondisi kayu akan mengarah pada ketiadaan kandungan pati di dalam kayu. Kondisi demikian akan menghindarkan kayu tersebut dari serangan serangga penggerek kayu, sehingga bila kayu ini kelak digunakan sebagai komponen bangunan, maka kayu tersebut akan menjadi lebih awet karena terbebas dari serangan serangga penggerek kayu.

Dari uraian di atas, jelaslah bahwa proses peneresan batang selama satu atau dua tahun sehingga batang pohon itu menjadi "alum" sebelum pelaksanaan proses penebangan, akan menghasilkan kayu gergajian yang berkualitas tinggi dan rendemen kayu gergajian yang tinggi pula. Di samping itu, kayu juga menjadi lebih awet karena terhindar dari serangan serangga.

Dengan kata lain, peneresan pohon sebagai salah satu wujud teknologi kayu yang berbasis pada kearifan tradisional masyarakat etnik jawa dan secara naluriah telah diterapkan selama berabad-abad itu ternyata mendapatkan pembenarannya secara akademis, meskipun pembenaran ini baru terumuskan di Eropa pada pertengahan abad kedua-puluh. Dengan demikian, nenek moyang masyarakat etnik Jawa melalui praksis kehidupannya, mampu mengenali adanya fenomena "tegangan pertumbuhan" pohon. Meskipun fenomena itu tidak mampu dijelaskannya secara rasional, masyarakat etnik Jawa berdasarkan pada nalurinya tetap menggunakan fenomena itu sebagai basis untuk melakukan aktivitas peneresan. Pada saat ini, peneresan pohon yang telah menjadi kekayaan budaya tradisional masyarakat etnik Jawa itu juga dipraktekkan pada proses penebangan pohon oleh Perum Perhutani, suatu perusahaan milik negara yang diserahi tugas untuk mengelola hutan jati secara moderen di Pulau Jawa dan Pulau Madura. Peneresan pohon bahkan telah menjadi satu aktivitas penting di dalam praktek pengelolaan terhadap hutan alam di tingkat nasional, khususnya di dalam rangka mematikan pohon demi pengendalian jenis pohon penyusun hutan alam tersebut.

\section{Daftarpustaka}

Archer, R.R., 1986. Growth Stress and Strain in Trees. Springer-Verlng. Berlin, Jermany.

Brady, 1981. The Nature and Properties of Soil. McGrawHill Incorporation. New York.

Kollmann, F.E.P., dan Cote, W.W., 1968. Principle of Wood Science and Technology. Springer-Verlag. New York Incorporation.

Prayitno, T.A., 2007. Pertumbuhan dan Ekstraktif. Program Studi Ilmu Kehutanan, Fakultas Kehutanan, Universitas Gadjah Mada. Yogyakarta.

Sabarnurdin, S., 1978. Fisiologi Pohon. Yayasan Pembina Fakultas Kehutanan, Universitas Gadjah Mada. Yogyakarta.

Soenardi, 1977. Ilmu Kayu. Yayasan Pembina Fakultas Kehutanan, Universitas Gadjah Mada. Yogyakarta.

Yamamoto, H., Wahyudi, I., Pari, G., Yoshida, M., Watanabe, H., Hadi, Y.S., dan T., Okuyama, 1988. Wood Quality of Teak (Tectona grandis) Planted in West Java, A Preliminary Studi. Dalam Proceeding of the Second International Wood Science Seminar. JSPS-LIPI Core University Program In the Field of Wood Science. Serpong. Indonesia. 